\title{
New Taxon of Fungal Endophytes from Phrynium capitatum Willd: A Promising Ethnomedicinal Plant in Northeast India and its Systematic and Phylogenetic Analysis
}

\author{
Richa Sharma ${ }^{1}$, Sumpam Tangjang ${ }^{2}$ and Amritesh C. Shukla ${ }^{3 *}$ \\ ${ }^{1,2}$ Department of Botany, Rajiv Gandhi University, Rono Hills, Doimukh, \\ Itanagar-791112 Arunachal Pradesh, India \\ ${ }^{1,3}$ Department of Botany, University of Lucknow, Lucknow-226007, Uttar Pradesh, India \\ E-mail: ${ }^{3 *}$ amriteshcshukla@gmail.com
}

\begin{abstract}
The findings of the current study deal with the first time report on the diversity of fungal endophyte from the ethnomedicinal plant- Phrynium capitatum Willd., (Marantaceae). The plant is growing wildly in the forest of Papum Pare, Arunachal Pradesh, India, and traditionally been used for anti-diabetic, antihyperglycemic or analgesic effects. During the investigation, samples of the plant parts, viz., leaves, stem, and roots were collected for isolation of endophytic spp. The endophytic spp were identified based on the morphological, cultural, and reproductive structures (hyaline, ellipsoidal, aseptate, pycnidia, beta conidia, perithecia, asci, and ascospores). Further, the phylogenetic analysis of the isolated species was made, using the sequences of 5.8S and 28S rDNA internal transcribed spacer sequence 1 and 4 . The largest number of fungal endophytes (39\%) were isolated from the leaves, followed by the roots (31\%) and stems (30\%). Overall 35 fungal species have been isolated, out of which, thirty-four belongs to the class Ascomycetes, and one from the class zygomycetes. The highest species richness and frequency of colonization were recorded in the leaf. The observations show that Pestalotiopsis longiseta was the most dominant endophytic species followed by Diplodina microsperma, Nodulisporium hinnuleum, Aspergillus flavus , Diaporthe sp., Nigrospora oryzae and Lasiodiplodia viticola. However, Pestalotiopsis neglecta, Sordaria fimicola, Diplodina microsperma, Fusarium incarnatum, Preussia sp., Diaporthe sp., Aureobasidium sp.were common fungal endophytes isolated from P. capitatum
\end{abstract}

Keywords: Biodiversity, Colonization Frequency, Endophyte, Internal Transcribed Spacer, Medicinal Plant, Arunanchal Pradesh

\section{INTRODUCTION}

De Barry (1866) coined the term 'endophyte' to detect fungi that live intercellulary and intracellularly in plants tissues causing no harm to the plant (Compant et al., 2017; Jeewon et al., 2017). Further, based on their interactions with host plants, fungal endophytes may be divided into three groups: commensalists, parasites, and mutualists (Jia et al., 2016, Kirschner 2018). In mutualism, definite fungal endophytes give tolerance to abiotic and biotic stresses on their host plants, improve their growth, and restrain diseases (Redman 2002, Rodriguez 2008). These Endophytes protect their hosts from infectious agents and adverse conditions by secreting bioactive secondary metabolites
(Nath et al., 2012; Nongalleima et al., 2013). Endophytic fungi were reported in almost all the plants spp. algae, ferns, mosses and mainly in gymnosperms, angiosperms reported from various parts of the world (Radic and Strukelj 2012; Doilom et al., 2017). Many researchers have proven that endophytes are the potential source of novel natural products for exploitation in modern medicine, agriculture and industry (Kaul et al., 2013). To date, it has been found that taxol can be produced by endophytic fungi Metarhizium anisopliae and Cladosporium cladosporioides (El-Maali et al., 2018). However, fungal endophytes can be easily grown in labs under routine culture techniques, and hence the potential for discovering a virtually inexhaustible supply of metabolites is high. Fungal endophytes can 
produce compounds similar to their host plants and are capable of preserving the world's diminishing biodiversity (Bender et al., 2016; Mane et al., 2017).

Studies on fungal endophytes concentrated on medicinal plants have shown that the curative property of the medicinal plant is not only because of the chemicals present in the plant but also because of the fungal endophytes that present in the plant (Verma 2011; Suryanarayanan 2013). Thus there is a need to isolate and identify several fungal endophytes and explore the potency of their secondary metabolites. Although, number of studies have already been reported in the association of fungal endophytes with medicinal plants from India viz., Clerodendron serratum, Pongamia, Ashwagandha, Taxus brevifolia, Azadirachta indica, Terminalia arjuna, Trigonella, foenum graecum, Labelia nicotinifolia, Adhatoda zeylanica, Bauhinia phoenicea,Catharanthus roseus, Parthenium hysterophorus, Ficus religiosa, Coffea Arabica, Crataeva magna, Silybum marianum, Allium sativum, Mamordica chaeantia, Azadarichata indica and Nothapodytes nimmoniana, (Tejesvi et al., 2005; Mane et al., 2017; Mane and Vedamurthy 2018), but there is no such report on fungal endophytic association with P. capitatum.

\section{MATERIALS \& METHODS}

\section{STUDY AREA}

The study area Papum Pare is located at the N $26^{\circ} 56^{\prime} 11^{\prime \prime}$ to $27^{\circ} 35^{\circ} 44^{\prime \prime}$ and E $93^{\circ} 12^{\prime} 45^{\prime \prime}$ to $94^{\circ} 13^{\prime} 30^{\prime \prime}$ is one of the important hotspots in the world, ranked 25th (Chowdhery 1999), and among the 200 globally important eco-regions (Olson and Dinerstein 1998). It covers an area of 2875 sq. $\mathrm{km}$, having an annual rainfall of $2694 \mathrm{~mm}$. Major part (75\%) of this district is covered by thick forest which has a sub-tropical, deciduous and humid type of vegetation (Fig.1-a).

\section{Plant \& Sample Collection}

The selected plant, $P$. capitatum is a semi-evergreen herb with creeping rootstock and is wildly growing in forest area (Papum Pare) in Arunanchal Pradesh (Fig. 1-b). Leaves oblong, acuminate, base rounded or obtuse, to $30 \times 18 \mathrm{~cm}$; petiole to $60 \mathrm{~cm}$ long, spike globose, sessile on the petiole, 4- 6 $\mathrm{cm}$ across. Inner bracts ovate-oblong, fimbriate at the apex, corolla yellow, outer petaloid staminodes orange-red, lip with a pendulous appendage, ovary tomentose (Anon 2019).

Samples of leaves, stems, and roots were collected during (Dec 2016- Dec 2018) from the healthy plant of $P$. capitatum in sterile bags and brought to the laboratory for processing within 24 hours after sampling.

\section{SURFACE STERILIZATION AND ISOLATION}

The samples thus collected were washed gently in running tap water to remove the soil and debris. Further, isolation of fungal endophytes was determined, using the method of Suryanarayanan et al., (1998). Samples were cut into small pieces of $(0.5-1.0 \mathrm{~cm})$. The pieces were then surfacesterilized by dipping them serially in $70 \%$ ethanol for $5 \mathrm{sec}$ and $4 \% \mathrm{NaOCl}$ for $90 \mathrm{sec}$; finally rinsed in sterile distilled water for $10 \mathrm{sec}$. Now, 150 segments of the samples were selected randomly and plated on Potato Dextrose Agar (PDA) medium (supplemented with $150 \mathrm{mg} / \mathrm{L}$ chloramphenicol) contained in Petri dishes (7.5 cm diam). Petri dishes were incubated ( $12 \mathrm{~h}$ dark: $12 \mathrm{~h}$ light cycle) for 25 days at $25 \pm 2{ }^{\circ} \mathrm{C}$, to observe the growth of endophytes, following the method of Suryanarayanan (1992). The hyphal tips which grew out from the segments were isolated and subcultured on PDA medium and preserved at $4^{\circ} \mathrm{C}$ for further investigation.

Further, the colonization frequency (CF) was calculated, using the following formula (Suryanarayanan et al., 2003):

$$
\text { CF\% }=\frac{\text { Number of segments colonized by fungal endophytes }}{\text { Total number of segment observed }} \times 100
$$

However, the density of colonization (rD\%) of a single endophyte species was calculated, using the method of Fisher and Petrini (1987).

$\mathrm{rD} \%=(\mathrm{Ncol} / \mathrm{Nt}) \times 100$

Where,

$\mathrm{Ncol}=$ Number of segments colonized by each fungus

$\mathrm{Nt}=$ Total number of segments inoculated

\section{MORPHOLOGICAL IDENTIFICATION}

We identified the endophytes thus isolated based on their macroscopic and microscopic characteristics viz., the morphology of fruiting structures and spore morphology (Sutton 1980; Subramanin 1983 and Nagmani 2005). 


\section{MOLECULAR IDENTIFICATION}

\section{DNA EXTRACTION AND PCR AMPLIFICATION OF RDNA}

Genomic DNA was extracted from fresh fungal mycelia growing on PDA plates (at $25 \pm 2{ }^{\circ} \mathrm{C}$ and 5 to 8 days old), using a Qiagen microbial extraction kit. Fragments of $18 \mathrm{~S}$ rRNA gene were amplified by PCR, using forward ITS1 (5'-TCCGTAGGTGAACCTGCGG-3') and reverse ITS4 (5'TCCTCCGCTTATTGATATGC-3') primer (White et al., 1990). Each PCR amplification reaction was performed in a final volume of $25 \mu \mathrm{L}$ containing $25 \mathrm{ng}$ template DNA, 10X PCR buffer (10 mM Tris-HCl, $50 \mathrm{mM} \mathrm{KCl,} \mathrm{pH} \mathrm{8.3),} 1.5 \mathrm{mM} \mathrm{MgCl2,}$ $200 \mu \mathrm{M}$ of each dNTP, $50 \mathrm{pM}$ of each primer, 1 unit of Taq polymerase (Genei, Banglore) and distilled water (Sigma, USA). The conditions of the PCR was initial denaturation at $95^{\circ} \mathrm{C}$ for 5 minutes followed by 35 cycles for $45 \mathrm{sec}$, annealing at $56{ }^{\circ} \mathrm{C}$ for 1 minute ( 35 cycles) and primer extension at $72{ }^{\circ} \mathrm{C}$ for 1 minute (again 35 cycles), final extension at 72 ${ }^{\circ} \mathrm{C}$ for 7 minutes ( 1 cycle) and hold (cooling) at $4{ }^{\circ} \mathrm{C}$. PCR products were checked on $1.2 \%$ Agarose gel in Trisacetate-EDTA buffer (TAE) at pH 8.0, stained with ethidium bromide $(0.3 \mathrm{~g} / \mathrm{mL})$ and visualized under UV light by using Gel documentation system. Sequencing was done by GeNei Labs Private Limited, Bengaluru using PRISM® BigDyeTM Terminator Cycle Sequencing Kits with AmpliTaq® DNA polymerase, as per the manufacturer instructions. Obtained Sequences were subjected to BLAST (Basic Local Alignment Search Tool). All obtained sequences were submitted and awarded access numbers in GenBank of NCBI (Table 1).

\section{PHYLOGENETIC ANALYSIS}

The primer pairs ITS1/ITS4 (White et al., 1990) were used to amplify ITS-rDNA and partial. The reaction mixture and thermal cycling conditions were the same as described by Karimi et al. (2016). The data thus sequenced was subjected to BLAST (Basic Local Alignment Search Tool), for homology search and multiple sequence alignments were made by ClustalW. Phylogenetic relationship of all fungal species; drawn their phylogenetic relationship. Further, it was analyzed using Neighbor-Joining methods of MEGA 5 (Tamura et al., 2011); and the robustness of the inferred phylogeny was assessed using bootstrap value at 1,000 replications.

\section{RESULTS}

The findings of the present investigation deal with the isolation of endophytic fungi, from P.capitatum; an ethnomedicinal plant commonly used to treat various ailments in human beings. The samples of the plants were collected randomly from the study area (Papum Pare). Out of total of 15 plant materials of $P$. capitatum, 150 segments were processed (including root, stem and leaves plant parts); for the isolation of endophytic fungi. The observations recorded total of 127 isolates of endophytic fungi; which belong to 35 fungal spp. The maximum number of fungal isolates were recorded from leaves (39\%), followed by roots $(31 \%)$ and stems (30\%) [Fig. 1-c], respectively; however, the colonization frequency rate was recorded highest in leaves $(80 \%)$ followed by roots (70\%) and stem (59.61\%). Total of 35 fungal endophytes were isolated, which belongs to 25genera.The observations show that Pestalotiopsis longiseta was the most dominant endophytic fungi, isolated from the selected plant (P.capitatum); followed by Diplodina microsperma, Nodulisporium hinnuleum, Aspergillus flavus, etc. However, Pestalotiopsis neglecta, Sordaria fimicola, Diplodina microsperma, Fusarium incarnatum, Preussia sp., Diaporthe sp. and Aureobasidium sp. were the common fungal endophytes recorded from all the plant parts viz., leaf, stem, and roots. While, isolating the organ-based fungal endophytes; it was recorded highest in leaves viz., Biscogniauxia mediterranea, Nodulisporium hinnuleum, Corynespora cassiicola, Scopulariopsis brevicaulis, Aspergillus nidulans and $A$. fischeri; followed by Curvularia borreriae, Nigrospora oryzae, Lasiodiplodia pseudotheobromae, $L$. viticola and Chaetomium globosum from the stem as well as Mucor hiemalis, Bipolaris bicolor and fungal Endophyte sp., from the roots. Besides, the density of colonization (rD\%) was recorded in the chronology of $P$. longiseta $(14 \%)<D$. microsperma $(6 \%)<N$. hinnuleum $(5.33 \%)<$ S. fimicola (4\%), and $0.66 \%$ to $4.00 \%$ for the remaining endophytes (Table 1; Fig. 2).

The analysis of fungal taxonomy of all the isolated 35 fungal endophytes shows that 14 endophytic fungi belong to class- Sordariomycetes; 13 belongs to the class Dothideomycetes; 06 belongs to the class Eurotiomycetes; 01 belong to the class Zygomycetes and 01 could not identify properly. While categorizing up to the order level; it was observed that $C$. borreriae, $C$. spicifera, C. cassiicola, Alternaria sp. B.bicolour, P. chartarum, Preussia sp., Phoma sp. and P. brabeji belongs to the order Pleosporales; 
A.niger, A. flavus, A. nidulans, A. fischeri, A. fumigates and $P$. chrysogenum belongs to the order Eurotiales; $D$. microsperma, F. merismoides and $F$. incarnatum belongs to the order Hypocreales; P. longiseta, B. mediterranea, $N$. hinnuleum and Eutypa sp.belongs to the order Xylariales; S. fimicola and C. globosum belongs to order Sordariales; $L$. pseudotheobromae and $L$. viticola belongs to order Botryosphaerial; $C$. fructicola and C. gloeosporioides belongs to the order Glomerellales; Dothidea sp., Aureobasidium sp. belongs to the order Dothideales; Besides this, 02 fungal endophytes belong to order Mucorales viz., M. hiemalis, $S$. brevicaulis; 01 fungal endophyte $N$. oryzae belongs to the orders Trichosphaeriales, and one Diaporthe sp. belongs to the orders Diaporthales, respectively.

Samples of the fungal endophytes thus isolated (35 samples) were used for extraction of the DNA and its molecular characterization and submitted to the NCBI and got the accession number (Table 1). Further, phylogenetic analyses based on the ITS1-ITS4 sequencing data of the isolated fungal endophytes were also recorded. The observations of the neighbor-joining tree as constructed based on the sequence-structure alignment, and recorded in figure two; shows the structure alignment clearly in five well-separated groups. Group 'A' consisted of L. viticola, Alternaria sp., P.brabeji, P.chrysogenum, Fincarnatum, Aureobasidium sp., $P$. longiseta, and $C$. cassiicola where only P. brabeji and P.chrysogenum show strong bootstrap value. Similarly, Group 'B' consisted of C. globosum, C. spicifera, S.brevicaulis, A. fumigates and Phoma sp. Group 'C' contains F. merismoides, Preussia sp., B. bicolor, L. pseudotheobromae A.fischeri, C.gloeosporioides, B. mediterranea. Group ' $\mathrm{D}$ ' contains S. fimicola, A.niger, Eutypa sp., Diaporthe sp., C. fructicola. .However, group ' $\mathrm{E}$ ' consisted P. longiseta, Dothidea sp., Fungal Endophyte sp., D. microsperma, C.borreriae, N.hinnuleum, M. hiemalis, P. chartarum, A. flavus, N. oryzae (Fig. 3).

The findings also show that there is not any such type of report on the isolation of endophytic fungi from $P$. capitatum as investigated in the current study; it indicates itself the uniqueness of the work as the first report.

\section{DISCUSSION}

Literature reveals that diversity of fungal endophytes have already been reported from several medicinal plants viz., Aspergillus candidus, Nigrospora oryzae, Cladosporium cladosporioides and Rhizoctonia solani reported from Ananas comosus (Krishnamurthy et al., 2008); Fomitopsis sp. Penicillium sp., Diaporthe sp., Arthrinium sp. Phomopsis sp. and Schizophyllum sp. have been reported from Garcinia mangostana and G.parvifolia (Sim et al., 2010); Mortierella minutissima, N. sphaerica, Acremonium strictum, Humicola Grisea, Mortierella hyaline, Oidiodendron echinulatum, 0. griseum, Humicola fuscoatra and Arthroderma tuberculatum reported from Elaeocarpus sphaericus (Shukla et al., 2012); Phoma tropica, Cladosporium sphaerospermum, Xylaria sp., Phomopsis archeri, and Tetraploa aristata from Opuntia ficus-indica (Bezerra et al., 2012); Phomopsis spp, Diaporthe spp, Schizophyllum spp, Penicillium spp, Fomitopsis spp and Arthrinium spp from Cinchona spp. (Maehara et al., 2013); A. alternata, Phomopsis sp. and Fomitopsis sp. from Miquelia dentate (Shweta et al., 2013); F. oxysporum,Talaromyces radicus and Eutypella spp. From Catharanthus roseus (Kuriakose et al., 2016); Altenaria alternata, C. capsici, and C. taiwanense from Passiflora incarnate (Seetharaman et al., 2017); Penicillium sp., P. griseofulvum, A. flavus, Mycoleptodiscus terrestris, Trichoderma sp., C. gloeosporioides and Shiraia sp. from Huperzia serrata (Su et al., 2017); P.citrinum, A. alternate, A. niger, Cladosporium sp., Rhizopus sp., C.vermiformis reported from Helicteres isora (Gayathri and Chandra 2017); Periconia hispidula, Allomyces arbuscula, N. sphaerica, A. falciforme, P. chrysogenum Aureobasidium sp. Chaetomium sp. from Litsea cubeba (Deepanwita and Dhruva 2018); and Fusarium spp, Aspergillus sp.,, Chaetomium sp.,, Penicillium sp., Setosphaeria rostrata, Fsolani, Bipolaris maydis, D.phaseolorum, Rhizoctonia bataticola, and Macrophomina phaseolina reported from Chlorophytum borivilianum (de Carvalho et al., 2019) as well as A. alternata, A. terreus, Alpestrisphaeria reported from Vitex rotundifolia (Yu-Hung Yeh and Roland Kirschner 2019). However, there are no such reports of the fungal endophytes on P. capitatum; as recorded in the present investigation.

In the current study, overall 127 species of endophytic fungi; which belong to 35 fungal spp have been isolated from the plant parts including leaves (39\%), followed by roots (31\%) and stems (30\%), respectively [Fig. 1c]. Further, it was observed that Pestalotiopsis longiseta was the most dominant endophytic fungi followed by Diplodina microsperma, Nodulisporium hinnuleum, Aspergillus flavus and others. However, Pestalotiopsis neglecta, Sordaria fimicola, Diplodina microsperma, Fusarium incarnatum, Preussia sp., Diaporthe sp. and Aureobasidium sp.were the common fungal endophytes recorded from all the plant parts viz., leaf, stem and roots as well as the density of colonization ( $\mathrm{rD} \%)$ was recorded for P. longiseta $(14 \%)<$ D. microsperma $(6 \%)<N$. hinnuleum $(5.33 \%)<S$. fimicola (4\%), and $0.66 \%$ to $4.00 \%$ for the remaining endophytes 
(Table 1; Fig. 2). Furthermore, the fungal taxonomy of all the isolated 35 fungal endophytes was also recorded. Sordariomycetes was the class represented the maximum endophytes (14), however, Zygomycetes was the class with the least representation (01). Besides this, extraction of the DNA and its molecular characterization as well as phylogenetic analyses based on the ITS1-ITS4 sequencing data of the isolated thirty-five fungal endophytes, have also been investigated and recorded in Table -1 .

Furthermore, literature also reveals that fungal endophytes mimic the plants behavior and function and also are capable to produce bioactive compound/ secondary metabolites as novel compounds having antimicrobial, anticancer, antioxidants, insecticidal, anti-malaria, antituberculosis, anti-diabetes mellitus and cure cancer and cytotoxic activity (Das et al., 2012; Desale 2016; Kumar and Mongolla, 2018). Biology of fungal endophytes has useful in several clinical applications with molecular approaches and fungal endophytes may assist to improve the activity of drug research area. Fungal endophytes nanoparticles may be used to improve plant growth, as bio- fertilizers, enhance crop yield and soil fertility (Netala et al.,, 2016; Mohamed et al., 2019). Secondary metabolites produced by fungal endophytes used various field of food, and pharmaceutical, agricultural and other related industries (Das et al., 2012; Desale 2016; Netala et al., 2016; Kumar and Mongolla, 2018; Mohamed et al., 2019). Similarly, in the present study, some of the endophytic fungi have also been recorded to have antimicrobial efficacy.

\section{ACKNOWLEDGEMENTS}

The authors are thankful to the tribal peoples of Arunanchal Pradesh, for providing ethnomedicinal information about the particular plant and its uses for various ailments. Further, authors are also thankful to the Head Department of Botany, Rajiv Gandhi University, Arunanchal Pradesh as well as to the Head Department of Botany, the University of Lucknow for providing various facilities during the present study. Besides this, one of the authors is thankful to the MHRD, Govt of India; for providing financial support.

\section{REFERENCES}

Anon (2019). India Biodiversity Portal, Species https:// indiabiodiversity.org/biodiv/species/show/258439

Bender SF, Wagg C,Van Der, Heijden MGA(2016) An underground revolution: biodiversity and soil ecological engineering for agricultural sustainability. Trends Ecol Evol 31(6): 440-452.
Bezerra JD, Santos MG, Svedese VM, Lima DM, Fernandes MJ, Paiva LM, Souza-Motta CM (2012) Richness of endophytic fungi isolated from Opuntia ficus-indica Mill. (Cactaceae) and preliminary screening for enzyme production. World J Microbiol Biotechnol 28:1989-1995

Chowdhery HJ (1999) Arunachal Pradesh; in Floristic diversity and conservation strategies in India, Vol. II: In the context of states and Union Territories (eds.) V Mudgal and PK Hajra Kolkata: Botanical Survey of India - pp 1059.

Compant S, Saikkonen K., Mitter B, Campisano A, Mercado-Blanco J (2017) Editorial special issue: soil, plants and endophytes. Plant Soil 405(1-2):1-11.

Das K, Das S and Tiwari RKS (2012). Bioprospecting of Endophytic Fungi for Bioactive Natural Products: Recent Trends and Future Perspectives. Microbiology Application (eds) pp. 346-364.

Desale MG (2016). Bioprospecting of Endophytic Fungi From Certain Medicinal Plants. PhD Thesis, Bharati Vidyapeeth Deemed University, Pune.

De Barry A (1866) Morphologie und physiologie der pilze, flechten, und myxomyceten, (Vol. II), Hofmeister's Handbook of Physiological Botany, Leipzig, Germany.

de Carvalho CR et al (2019) Bioactive compounds of endophytic fungi associated with medicinal plants. In: Yadav A, Singh S, Mishra S, Gupta A (eds) Recent Advancement in White Biotechnology Through Fungi. Fungal Biology. Springer, Cham.

Deepanwita D and Dhruva KJ (2018) Antimicrobial activity of Endophytic Fungi from leaves and barks of Litsea cubeba Pers., a Ttaditionally Important Medicinal Plant of North East India, Jordan Journal of Biological science pp 73-79.

Doilom M, Manawasinghe IS, Jeewon R, Jayawardena RS, Tibpromma S, Hongsanan, S, Meepol W, Lumyong S, Jones EBG, Hyde KD (2017) Can ITS sequence data identify fungal endophytes from cultures? A case study from Rhizophora apiculata. Mycosphere 8:1869-1892.

El-Maali N, Mohrram A, El-Kashef H, Gamal K (2018) Novel resources of Taxol from endophytic and entomopathogenic fungi: isolation, characterization and LC-Triple mass spectrometric quantification. Talanta 190: 466-474.

Fisher PJ and Petrini O (1987) Location of fungal endophytes in tissues of Suaeda fruticosa: A preliminary study. Trans. Brit. mycol. Soc 89:246-249.

Gayathri Pai and Chandra M (2017) Screening of Phytochemicals and Isolation of Endophytic Fungi from Medicinal plant Helicteres isora L." IOSR Journal of Pharmacy (IOSRPHR), vol. 7:12, pp. 01- 05 .

Jeewon R, Wanasinghe DN, Rampadaruth S, Puchooa D, Zhou LG, Liu AR, Wang HK (2017). Nomenclatural and identification pitfalls of endophytic mycota based on DNA sequence analyses of ribosomal and protein genes phylogenetic markers: a taxonomic dead end? Mycosphere 8(10): 1802-1817.

Jia ML, Chen HL, Xin CJ, Zheng K, Rahman T, Han and LP, Qin (2016) A Friendly Relationship between Endophytic Fungi and Medicinal Plants: A Systematic Review. Front. Microbiol 7: 906.

Karimi K, Khodaei S, Rota-Stabelli O, Arzanlou M, Pertot I (2016) Identification and Characterization of two new Fungal Pathogens of Polygonatum odoratum (Angular Solomon's seal) in Italy. J Phytopathol 164: 1075-1084. 
Kaul S, Ahmed M, Zargar K, Sharma P, Dhar MK (2013) Prospecting endophytic fungal assemblage of digitalis lanata Ehrh, (foxglove) as a novel source of digoxin: a cardiac glycoside, Biotechnology 3:335-40.

Kirschner R (2018) Fungi on the leaf-a contribution towards a review of phyllosphere microbiology from the mycological perspective. Biosyst. Ecol. Ser 34:433-448

Krishnamurthy YL, Naik SB, Jayaram S (2008) Communities in herbaceous medicinal plants from the Malnad region, Southern India. Microbes and Environments 23(1):24-28

Kumar CG and Mongolla P (2018) Bioprospecting of Endophytic Fungi for Bioactive Compounds. In: Gehlot P, Singh J (eds) Fungi and their Role in Sustainable Development: Current Perspectives. Springer, Singapore.

Kuriakose GC, Palem PP, Jayabaskaran C (2016) Fungal vincristine from Eutypella spp-CrP14 isolated from Catharanthus roseus induces apoptosis in human squamous carcinoma cell lineA431. BMC Complement Altern Med 16.

Maehara S, Simanjuntak P, Maetani Y et al (2013) Ability of endophytic filamentous fungi associated with Cinchona ledgeriana to produce Cinchona alkaloids. J Nat Med 67: 421-423.

Mane and Vedamurthy (2018) The fungal endophytes: Sources and future prospects, J Med Plants Stud 6(2): 121-126.

Mane RS, Shinde MB, Wagh PR, Malkar HM (2017) Isolation of endophytic microorganisms as a source of novel secondary metabolite producers against Tuberculosis. IJSART 3: 1267-1269.

Mohamed NH, Ismail1 MA, Abdel-Mageed WM and Shoreit AAM (2019). Antimicrobial activity of green silver nanoparticles from endophytic fungi isolated from Calotropis procera (Ait) latex. Microbiology 165(9): https://doi.org/10.1099/ mic. 0.000832 .

Nagmani AI, Kunwar Manoharachary KC (2005) Hand book of soil fungi. I. K. International Pvt. Ltd.

Nath A, Raghunatha P, Joshi SR (2012) Diversity and biological activities of endophytic fungi of Emblica officinalis, an ethnomedicinal plant of India. Mycobiology 40: 8-13.

Netala VR, Kotakadi VS, Bobbu P, Gaddam SA, Tartte V. Endophytic fungal isolate mediated biosynthesis of silver nanoparticles and their free radical scavenging activity and anti microbial studies. 3 Biotech. 2016;6(2):132. doi:10.1007/s13205-0160433-7

Nongalleima KH, Dey A, Deb L, Singh C, Biseshwori T, Devi HS and Devi SI (2013) Endophytic fungus isolated from Zingiber zerumbet (L.) Sm. inhibits free radicals and cyclooxygenase activity. International Journal of Pharm Tech Research 5: 301-307.

Olson DM, Dinerstein E (1998) The Global 200: A representation approach to conserving the Earth's most biologically valuable ecoregions. Conserv Biol 12: 502-515.

Radic N, Strukelj B (2012) Endophytic fungi- the treasure chest of antibacterial substances. Phytomedicine 19:1270-1284.

Redman RS, Sheehan KB, Stout RG, Rodriguez RJ and Henson JM (2002) Thermotolerance conferred to plant host and fungal endophyte during mutualistic symbiosis. Science 298:1581.

Rodriguez RJ, Henson J, Volkenburgh EV, Hoy M, Wright L, Beckwith F, Kim YO and Redman RS (2008) Stress tolerance in plants via habitat-adapted symbiosis. ISME J 2:404-416.
Seetharaman P, Gnanasekar S, Chandrasekaran R et al. (2017) Isolation and characterization of anticancer flavone chrysin (5,7-dihydroxyflavone)-producing endophytic fungi from Passiflora incarnata L. leaves. Ann Microbiol 67:321-331.

Shukla AK, Yongam Y and Tripathi P (2012) Distribution of endophytic fungi in different parts of Rudraksh (Elaeocarpus sphaericus) plants. In: Microbes: Diversity \& Biotechnology pp. 37-42.

Shweta S, Bindu JH, Raghu J et al (2013) Isolation of endophytic bacteria producing the anticancer alkaloid camptothecine from Miquelia dentata Bedd (Icacinaceae). Phytomed 20:913-917.

Sim JH, Khoo CH, Lee LH and Cheah YK (2010) Molecular diversity of fungal endophytes isolated from Garcinia mangostana and Garcinia.parvifolia. J.Microbiol. Biotechnol 20: 651-658.

Su J, Liu H, Guo K et al (2017) Research advances and detection methodologies for microbederived acetylcholinesterase inhibitors: a systemic review. Molecules 22.

Subramanian CV (1983) Hyphomycetes, Taxonomy and Biology, Academic Press London, Vol I \& II 930.

Suryanarayanan TS (1992) Light-incubation: a neglected procedure in mycology. Mycologist 6: 144.

Suryanarayanan TS (2013) Endophyte research: going beyond isolation and metabolite documentation. Fungal Eco 6: 561-568.

Suryanarayanan TS, Kumaresan V, Johnson JA (1998) Foliar fungal endophytes from two species of the mangrove Rhizophora. Canadian Journal of Microbiology .44: 1003-1006.

Suryanarayanan TS, Venkatesan G, Murali TS (2003) Endophytic fungal communities in leaves of tropical forest trees: Diversity and distribution patterns. Current Science 85(4), $489-492$

Sutton and Brian (1980) The coelomycetes. Commonwealth mycological institute kew, surrey, Engaland.

Tamura KD, Peterson N, Peterson G, Stecher M, Nei S Kumar (2011) MEGA5: Molecular Evolutionary Genetics Analysis using Maximum Likelihood, Evolutionary Distance, and Maximum Parsimony Methods. Mol Biol Evol 28: 2731- 2739.

Tejesvi MV, Mahesh B, Nalini MS, Prakash HS, Kini KR., Subbiah V and Hunthrike SS ( 2005) Endophytic fungal assemblages from inner bark and twig of Terminalia arjuna W. and A. (Combretaceae). World J Microbiol Biotechno l 21: $1535-1540$.

Verma VC, Gond SK, Kumar A, Kharwar RN, Boulanger LA and Strobel GA (2011) Endophytic fungal flora from roots and fruits of an Indian neem plant Azadirachta indica, A. Juss and impact of culture media on their isolation. Ind.J.of Microbiol 51:469-476.

White TJ, Bruns T, Lee S, Taylor J (1990) Amplification and direct sequencing of fungal ribosomal RNA genes for phylogenetics. In: Innis MA, Gelfand DH, Sninsky JJ, White TJ, editors. PCR protocols: a guide to methods and applications. New York: Academic Press, 315-322.

Yu-Hung Yeh and Roland Kirschner (2019) Diversity of Endophytic Fungi of the Coastal Plant Vitex rotundifolia in Taiwan, Microbes Environ Vol. 34: (1) 59-63. 


\section{New Taxon of Fungal Endophytes from Phrynium capitatum Willd}

Table 1: Fungal Endophytes Isolated from P. capitatum, its Frequency (CF \%), Density (rD\%) and Accession Number

\begin{tabular}{|c|c|c|c|c|c|c|c|}
\hline \multirow{2}{*}{ S. N. } & \multirow{2}{*}{ Isolated of Fungal Endophytes } & \multicolumn{3}{|c|}{ Plant parts } & \multirow{2}{*}{$\begin{array}{l}\text { CF } \\
(\%)\end{array}$} & \multirow{2}{*}{$\begin{array}{l}\text { rD } \\
(\%)\end{array}$} & \multirow{2}{*}{$\begin{array}{c}\text { NCBI } \\
\text { Accession No }\end{array}$} \\
\hline & & Leaf & Stem & Root & & & \\
\hline 1 & Pestalotiopsis longiseta & Leaf & Stem & Root & 42 & 14.0 & MK299129 \\
\hline 2 & Sordaria fimicola & Leaf & Stem & Root & 12 & 4.00 & MK299157 \\
\hline 3 & Curvularia borreriae & --- & Stem & --- & 10 & 3.33 & MK299132 \\
\hline 4 & Biscogniauxia mediterranea & Leaf & --- & -- & 4 & 1.33 & MK398255 \\
\hline 5 & Colletotrichum fructicola & -- & Stem & Root & 10 & 3.33 & MK299145 \\
\hline 6 & Diplodina microsperma & Leaf & Stem & Root & 18 & 6.00 & MK332492 \\
\hline 7 & Nodulisporium hinnuleum & Leaf & --- & -- & 16 & 5.33 & MK299151 \\
\hline 8 & Mucor hiemalis & --- & --- & Root & 6 & 2.00 & MK299138 \\
\hline 9 & Aspergillus niger & Leaf & --- & Root & 12 & 4.00 & MK248610 \\
\hline 10 & Nigrospora oryzae & --- & Stem & --- & 14 & 4.66 & MK299154 \\
\hline 11 & Corynespora cassiicola & Leaf & --- & -- & 6 & 2.00 & MK299155 \\
\hline 12 & Dothidea sp. & Leaf & Stem & -- & 8 & 2.66 & MK299156 \\
\hline 13 & Penicillium chrysogenum & Leaf & --- & Root & 6 & 2.00 & MK299147 \\
\hline 14 & Fusarium merismoides & Leaf & Stem & --- & 10 & 3.33 & MK299158 \\
\hline 15 & Alternaria sp. & Leaf & Stem & --- & 8 & 2.66 & MK332475 \\
\hline 16 & Aspergillus flavus & Leaf & --- & Root & 16 & 5.33 & MK332476 \\
\hline 17 & Bipolaris bicolor & -- & --- & Root & 2 & 0.66 & MK332477 \\
\hline 18 & Curvularia spicifera & Leaf & --- & Root & 8 & 2.66 & MK332478 \\
\hline 19 & Pithomyces chartarum & Leaf & Stem & --- & 2 & 0.66 & MK299154 \\
\hline 20 & Lasiodiplodia pseudotheobromae & --- & Stem & --- & 8 & 2.66 & MK248599 \\
\hline 21 & Scopulariopsis brevicaulis & Leaf & --- & --- & 10 & 3.33 & MK299149 \\
\hline 22 & Colletotrichum gloeosporioides & -- & Stem & -- & 6 & 2.00 & MH752465 \\
\hline 23 & Eutypa sp. & Leaf & Stem & -- & 8 & 2.66 & MK299142 \\
\hline 24 & Aspergillus nidulans & Leaf & --- & -- & 12 & 4.00 & MK299125 \\
\hline 25 & Fungal Endophyte sp & --- & --- & Root & 4 & 1.33 & MK248607 \\
\hline 26 & Fusarium incarnatum & Leaf & Stem & Root & 8 & 2.66 & MK299134 \\
\hline 27 & Lasiodiplodia viticola & -- & Stem & --- & 14 & 4.66 & MK398249 \\
\hline 28 & Aspergillus fischeri & Leaf & --- & -- & 10 & 3.33 & MH748593 \\
\hline 29 & Preussia sp. & Leaf & Stem & Root & 4 & 1.33 & MK398250 \\
\hline 30 & Phoma sp. & -- & Stem & --- & 6 & 2.00 & MK398251 \\
\hline 31 & Pseudocamarosporium brabeji & Leaf & -- & Root & 2 & 0.66 & MK398252 \\
\hline 32 & Aspergillus fumigatus & -- & Stem & root & 8 & 2.66 & MK398253 \\
\hline 33 & Diaporthe sp. & Leaf & Stem & Root & 16 & 5.33 & MK398254 \\
\hline 34 & Aureobasidium sp. & Leaf & Stem & Root & 10 & 3.33 & MK398283 \\
\hline 35 & Chaetomium globosum & --- & Stem & --- & 2 & 0.66 & MK398256 \\
\hline
\end{tabular}

--- indicates absences of the fungal endophytes. 

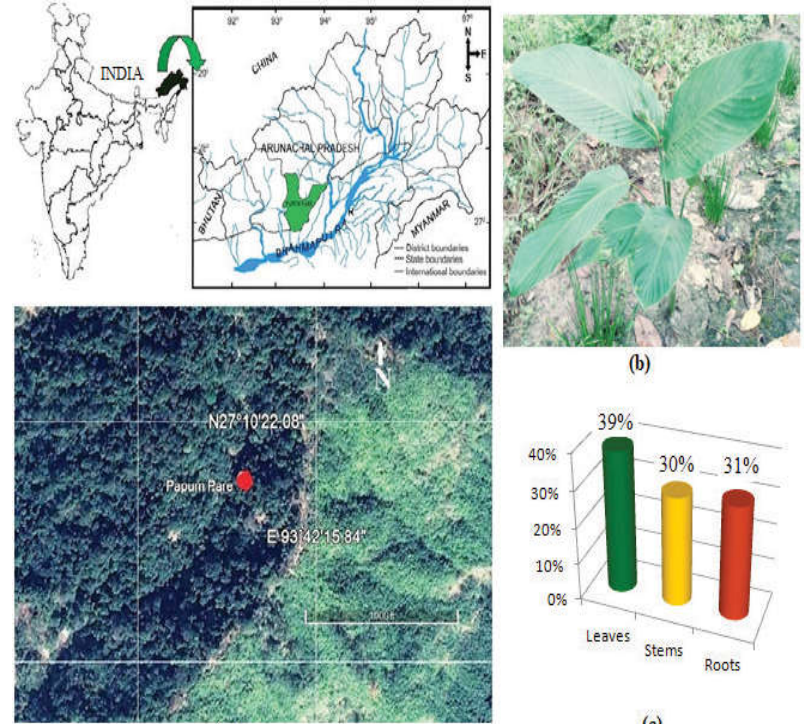

(b)

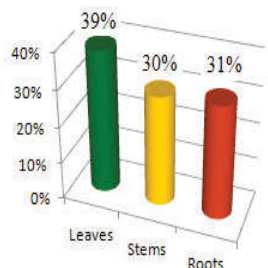

(c)

Fig. 1: Sample Collection Site of $P$. capitatum, in Arunachal Pradesh, India (Satellite Image), where, Red Circle Indicates Collection Site (b) Ethnomedicinal Plant $P$. capitatum, an Overview (c) Fungal Endophytes Isolated from Different Parts of $P$. capitatum

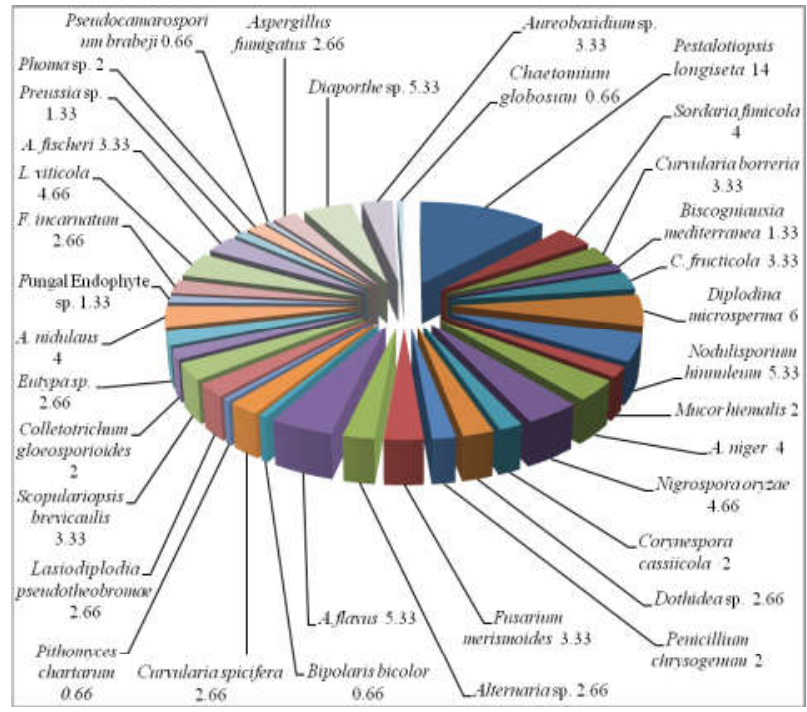

Fig. 2: Isolated Fungal Endophytes and its rD (\%) from P. capitatum

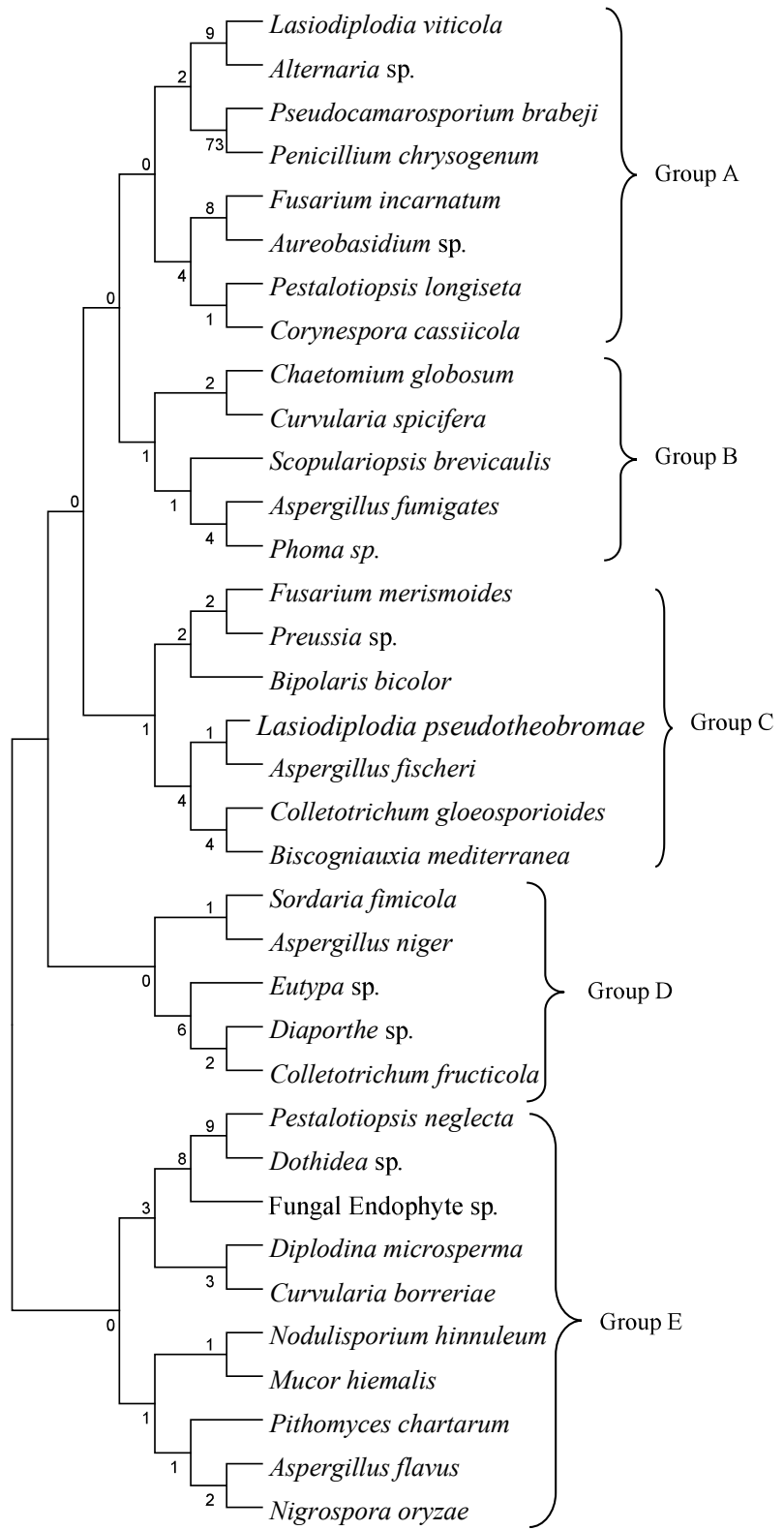

Fig. 3: Phylogenetic Analysis based on Neighbor-joining Tree based on ITS rDNA Sequences of the Isolated 35 Fungal Endophytes. Numerical Values Indicate Bootstrap Percentile from 1000 Iterations 